\title{
Successful Management of Ascites of Hepatic Origin in a Pup
}

\author{
A. Hemanth Srinivas*, T. Venkatesh, K. Lakshmi ${ }^{1}$ and J. Radha Krishna Rao ${ }^{2}$ \\ ${ }^{1}$ Department of Veterinary Medicine, College of Veterinary Science, Korutla, India \\ ${ }^{2}$ Department of Veterinary Clinical complex, College of Veterinary Science, Korutla, India
}

*Corresponding author

\section{A B S T R A C T}

\begin{tabular}{|l|}
\hline Ke y w o r d s \\
Ascites, Pup, \\
Management, \\
Hepatoprotectants \\
\hline Article Info \\
\hline $\begin{array}{l}\text { Accepted: } \\
\text { 15 December } 2019 \\
\text { Available Online: } \\
\text { 20 January } 2020\end{array}$ \\
\hline
\end{tabular}

\section{Introduction}

Ascites is referred as accumulation of serous fluid in the peritoneal cavity and generally manifested in several disease conditions like hepatic diseases, kidney failure, right side heart failure, hypoproteinaemia and various types of neoplasms. True ascites refer to accumulation of serous or serosanguinous fluid in peritoneal space (Pradhan et al., 2008). Ascites is only a clinical manifestation of an underlying disease condition. As the liver physiologically and anatomically diverse, there is no single test that adequately identifies hepatic disease or its underlying cause. For this reason, a battery of tests must be used to diagnose the Ascites. Ascites can be treated after diagnosis of underlying cause (Turkar $e t$ al., 2009). The present paper illustrated the diagnosis and management of ascites due to hepatic origin and its management in a pup.

\section{Case history and clinical observations}

A five month old female Dachshund pup was presented to the Veterinary clinical complex of the College of Veterinary Science, Korutla, Telangana, India with the history of reduced appetite, distended abdomen (Fig.1) and dysponea since 8 days. Clinical examination of dog revealed bilaterally enlarged abdomen assuming pear shaped with distended linea alba (Fig.2). Upon tactile percussion, fluid thrill wave was observed. The physical examination revealed body temperature $\left(102.3^{\circ} \mathrm{F}\right)$, pulse rate $(118 /$ minute $)$ and heart 
rate (129/minute). The visible mucous membrane was pale. Hematological examination revealed reduced haemoglobin $(9.63 \mathrm{gm} \%)$, TEC $\left(4.23 \times 10^{6} / \mu \mathrm{l}\right)$ count and elevated levels of TLC $\left.\left(28.52 \times 10^{3} / \mu 1\right)\right)$ with Neutrophilia (85\%), Lymphocytosis (13\%), Eosinophils (02\%), Monocytes (01\%) (Table -1). Biochemical analysis of the serum revealed elevated levels of ALT (193 U/L), AST (148 U/L), ALP (231U/L), Total bilirubin $(1.21 \mathrm{mg} / \mathrm{dl})$ with reduced levels of total protein $(4.28 \mathrm{~g} / \mathrm{dl})$, albumin $(2.04 \mathrm{~g} / \mathrm{dl})$, blood glucose $(78 \mathrm{mg} / \mathrm{dl})$ and normal values of BUN $(19.01 \mathrm{mg} / \mathrm{dl})$ and creatinine $(1.19 \mathrm{mg} / \mathrm{dl})$ (Table-2) levels.

\section{Treatment and Discussion}

Initially $10 \mathrm{ml}$ of ascitic fluid was removed from the abdomen by abdominocentesis. The dog was treated with Inj. Furosemide (Lasix) @ $2 \mathrm{mg} / \mathrm{kg}$ body weight BID intramuscularly, repeated for 7 days, followed by inj Ampicillin \& cloxacillin@ 10mg/kg body weight for 5 days, inj chlorpheniramine maleate@0.4ml intramuscularly for 3days, inj tribivet @0.8ml intramuscularly for 5 days along with oral supplementation of Liv 52 @ $3 \mathrm{ml}$ orally twice daily for 10 days.

Table.1 Hematological parameters in a dog affected with ascites of hepatic origin

\begin{tabular}{|c|c|l|l|}
\hline S.No & Parameters & Before Treatment & After treatment \\
\hline $\mathbf{1 .}$ & Hemoglobin $(\mathrm{g} / \mathrm{dl})$ & 9.63 & 10.82 \\
\hline $\mathbf{2}$, & Total erythrocyte count $\left(\mathrm{x} 10^{6} / \mu \mathrm{l}\right)$ & 4.23 & 4.95 \\
\hline $\mathbf{3 .}$ & Total leucocyte count $\left(\mathrm{x} 10^{3} / \mu \mathrm{l}\right)$ & 28.52 & 16.63 \\
\hline $\mathbf{4 .}$ & PCV $(\%)$ & 39.64 & 41.45 \\
\hline $\mathbf{5 .}$ & Neutrophils $(\%)$ & 85 & 67 \\
\hline $\mathbf{6 .}$ & Lymphocytes $(\%)$ & 23 & 29 \\
\hline $\mathbf{7 .}$ & Monocytes $(\%)$ & 01 & 01 \\
\hline $\mathbf{8 .}$ & Eosinophils $(\%)$ & 02 & 01 \\
\hline
\end{tabular}

Table.2 Biochemical parameters in a dog affected with ascites of hepatic origin

\begin{tabular}{|c|c|c|c|}
\hline S.No & Parameters & Before Treatment & After treatment \\
\hline $\mathbf{1 .}$ & ALT(U/L) & 193 & 128 \\
\hline $\mathbf{2}$ & AST(U/L) & 148 & 97 \\
\hline $\mathbf{3 .}$ & ALP(U/L) & 231 & 186 \\
\hline $\mathbf{4 .}$ & Total bilirubin $(\mathrm{mg} / \mathrm{dl})$ & 1.21 & 0.93 \\
\hline $\mathbf{5 .}$ & Total protein $(\mathrm{g} / \mathrm{dl})$ & 4.28 & 5.21 \\
\hline $\mathbf{6 .}$ & Albumin $(\mathrm{g} / \mathrm{dl})$ & 2.04 & 2.69 \\
\hline $\mathbf{7 .}$ & Blood glucose $(\mathrm{mg} / \mathrm{dl})$ & 78 & 104 \\
\hline $\mathbf{8 .}$ & BUN $(\mathrm{mg} / \mathrm{dl})$ & 19.01 & 18.76 \\
\hline $\mathbf{9 .}$ & Creatinine $(\mathrm{mg} / \mathrm{dl})$ & 1.19 & 1.09 \\
\hline
\end{tabular}


Figure.1 Distended abdomen in a pup affected with ascites of hepatic origin

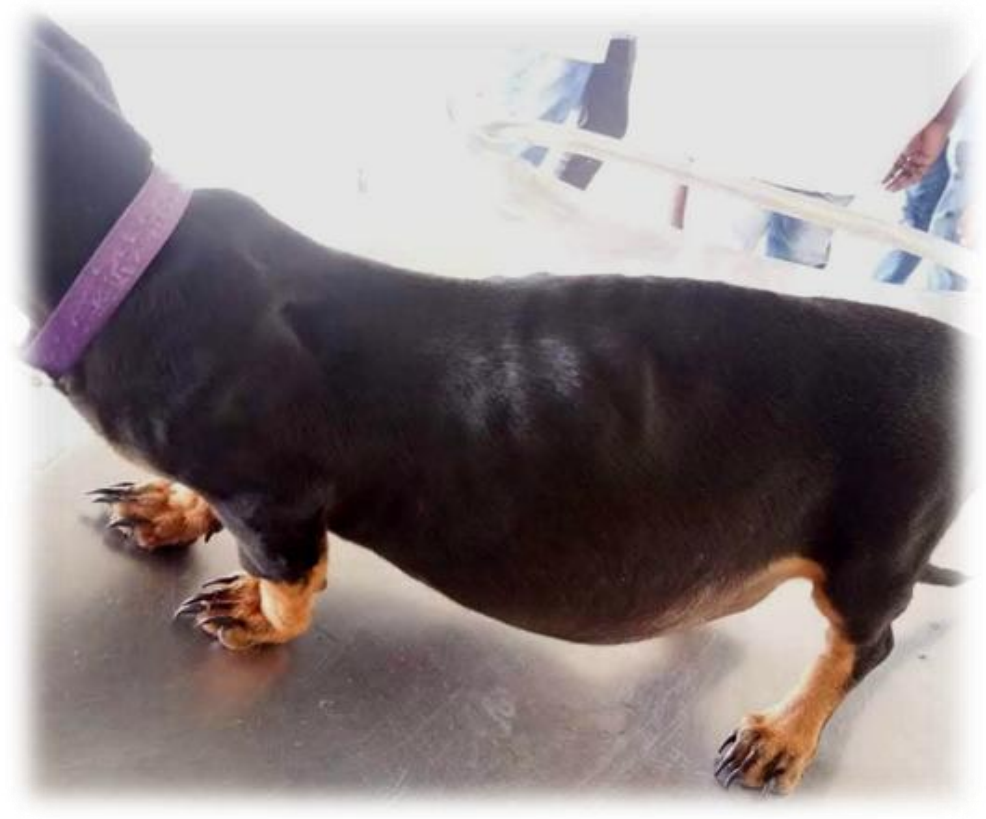

Figure.2 Pear shaped abdomen in a pup affected with ascites of hepatic origin

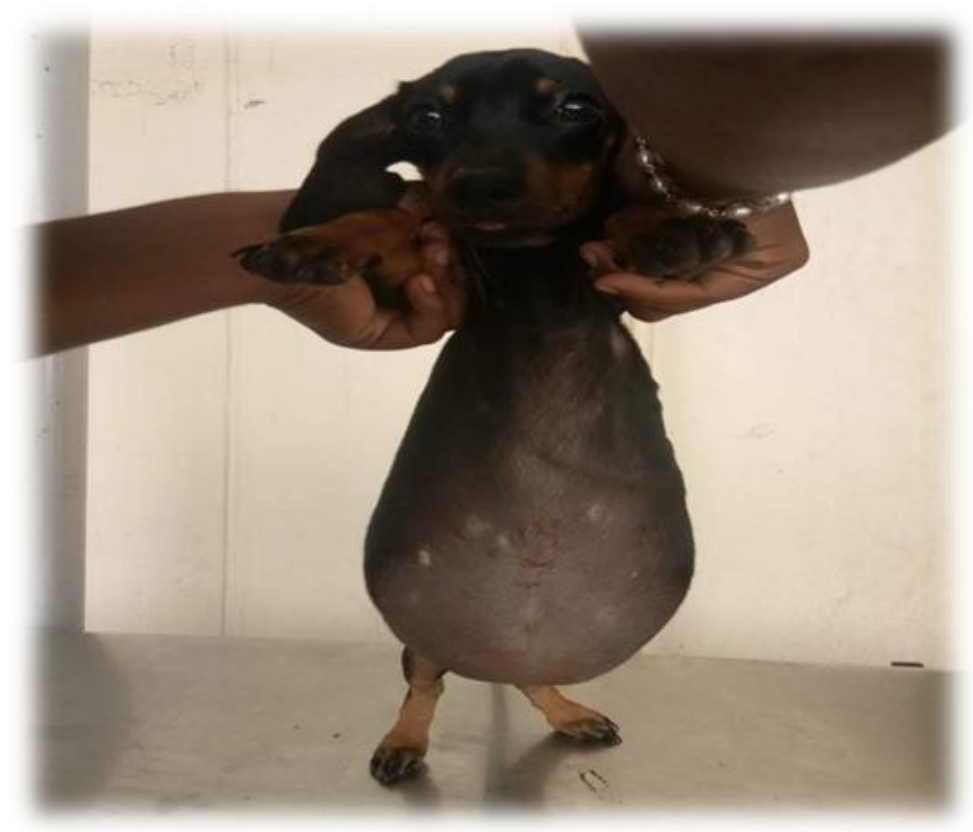


Fiure.3a Reduced distension of the abdomen in recovered pup after treatment.

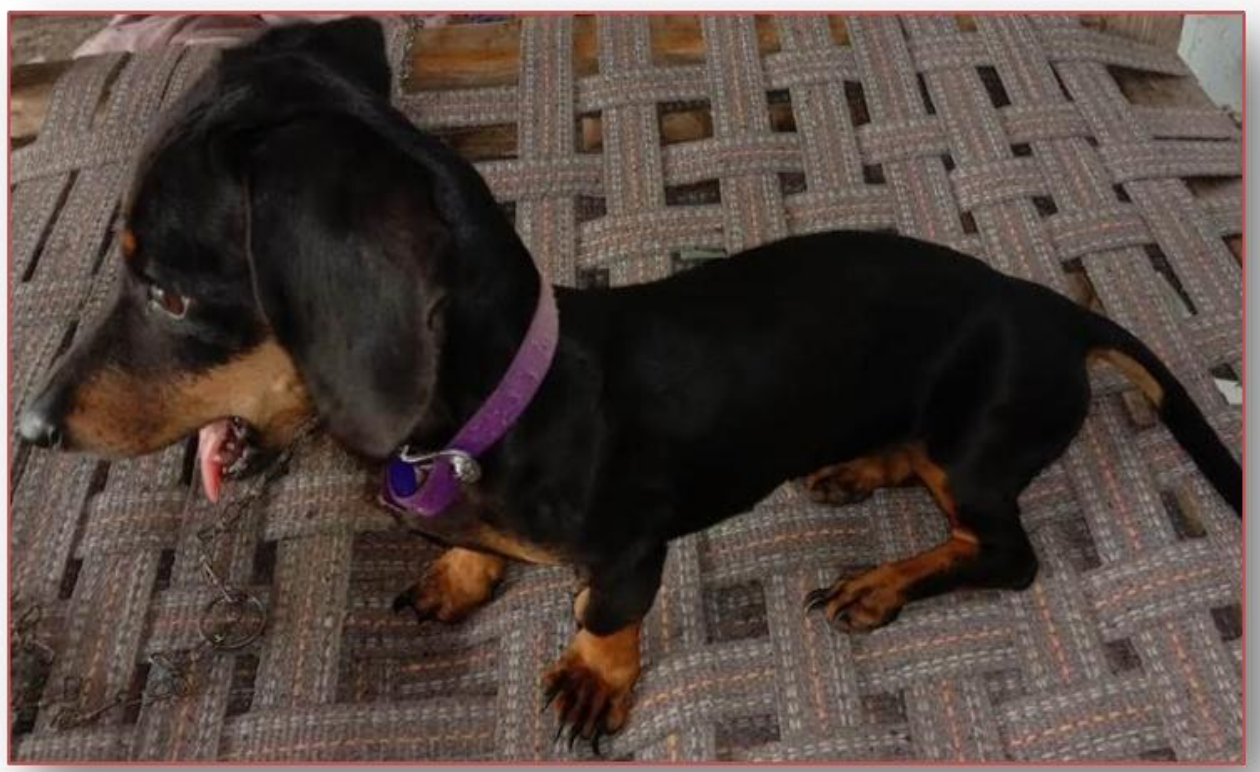

Figure.3b Reduced distension of abdomen after treatment [Top line view]

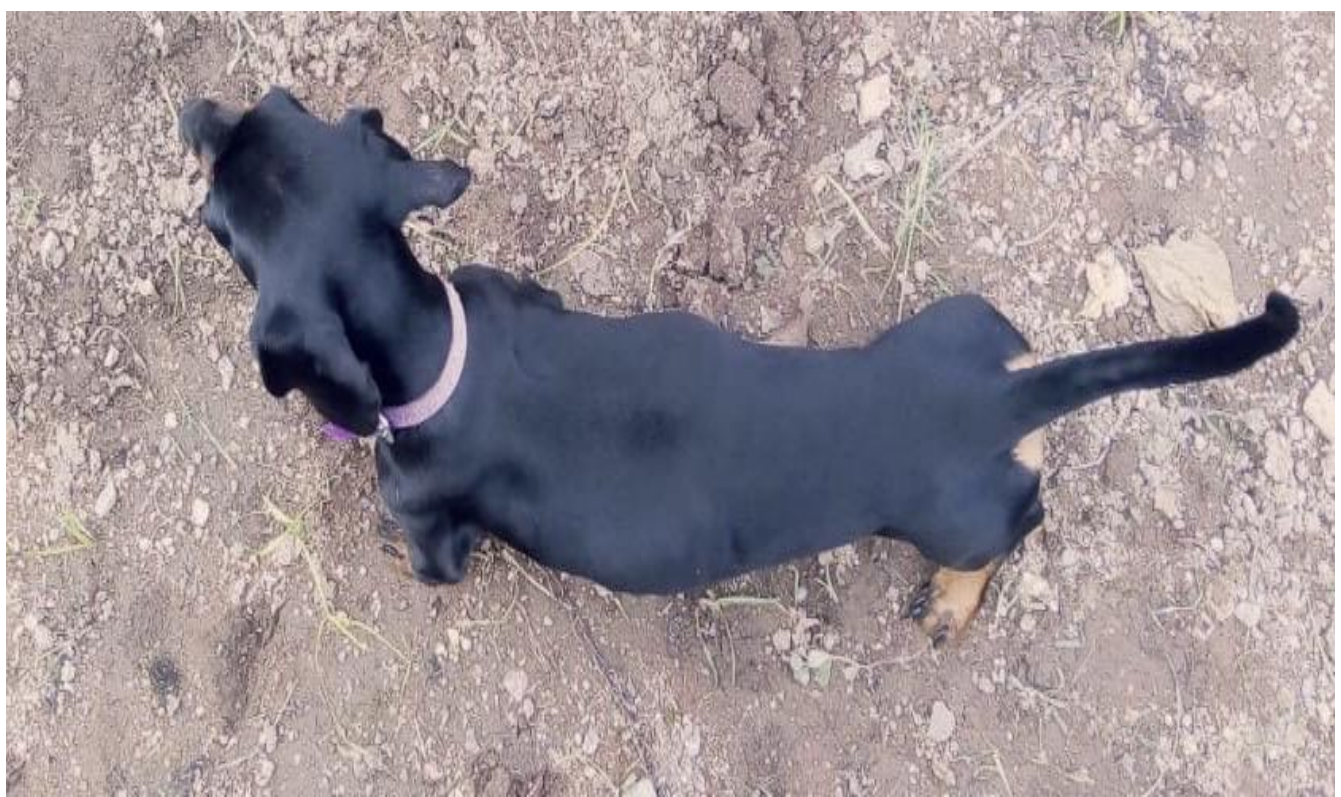

After 10 days, there was improvement in the condition of the pup with reduced distension of the abdomen (Figure-3) and improvement in the appetite. Improvement in the haematological and biochemical parameters was observed on day 10 (Table-2). The above findings were in agreement with Cornelius et al., (1975), Randhawa et al., (1988), Rakesh and Shanti (1994) and Kumar (2002). Increased SGOT indicates hepatic insufficiency with extensive damage which results leaking of enzyme into the 
bloodstream from hepatic cell (Cornelius et al., 1975). The values of BUN and creatinine levels were with in the normal range which indicated that, urinary functions appeared to be normal. Hence the renal involvement in this case is ruled out. Anaemia as observed in the present study may be because of hemorrhage or failure of erythropioesis and hemolysis. Elevations of plasma transaminases such as ALT, AST were indicative of altered hepatocellular necrosis and inflammation with degree proportional to number of injured hepatocytes (Pradhan et al., 2008). Hypoglycemia in the affected dogs might be due to inapetance/anorexia complemented by malabsorbtion from the intestines, decreased gluconeogenesis and glucogenolysis.

\section{Acknowledgements}

Authors are thankful to the P.V.N.R. Telangana Veterinary University for providing the facilities for the study.

\section{References}

Cornelius, L.M., Thrall D.E., Halliwell W.H., Frank G.M., Kern A.J. and Wood C.B. (1975): J. Am. Vet. Med. Assoc.
167:220-28.

Dabas VS, Suthar DN, Chaudhari CF, Modi LC, Vihol PD (2011). Ascites of splenic origin in a mongrel female dog - a case report. Veterinary World, 4:376-377.

Ettinger SJ, FeldmanEC (2005). Text book of Veterinary Internal Medicine; Disease of Dog and Cat.VI edn. WB Saunders, Philadelphia; pp 137-145.

Kumar KS and Srikala D, 2014. Diagnosis and management of cholecystitis in dogs. Int J Agric Sc Vet Med, 2(3): 1315.

Pradhan M S, Dakshinkar N S, Waghaya U G and Bodhke A M. (2008).Succesful treatment of Ascites of hepatic origin in a dog. Veterinary World, 23(1): 23-24.

Randhawa, S.S., Dhaliwal, P.S., Dua, S. and Singh, K.B. 1988. Ascites of hepatic origin in dogs. Indian Journal of Animal Health. 12: 165-166.

Rakesh and Shanti. 1994. Ascites in a bitch. Indian Journal of Veterinary Medicine. 18: 56-57.

TurkarS, Randhawa CS, Uppal SK (2009). Ascites associated with ancylostomiasis in a pup: A case report. Intas Polivet, 10:357-359.

\section{How to cite this article:}

Hemanth Srinivas, A., T. Venkatesh, K. Lakshmi1 and Radha Krishna Rao, J. 2020. Successful Management of Ascites of Hepatic Origin in a Pup. Int.J.Curr.Microbiol.App.Sci. 9(01): 269273. doi: https://doi.org/10.20546/ijcmas.2020.901.031 